\title{
POROVNANIE HYDRAULICKÝCH POMEROV V PRIMÁRNYCH ROZVODOCH TEPLA
}

\author{
COMPARISON OF HYDRAULIC CONDITIONS \\ IN PRIMARY HEATING NETWORKS
}

\author{
Martina Mudrá*,1, Ján Takács \\ "martina.mudra@stuba.sk \\ ${ }^{1}$ Slovenská technická univerzita v Bratislave, Stavebná fakulta, Katedra technických zariadení budov, Radlinského 11, 81005 Bratislava
}

\begin{abstract}
Abstrakt
Príspevok sa venuje porovnaniu hydraulických pomerov v primárnych rozvodoch tepla vybraného úseku sústavy centralizovaného zásobovania teplom. Porovnával sa výpočtový stav so skutočným stavom pred obnovou stavebných objektov a výpočtový stav s predpokladaným stavom po obnove stavebných objektov pripojených na sústavu centralizovaného zásobovania teplom. Ciel’om príspevku je prostredníctvom tlakových diagramov poukázat' na disproporcie, ktoré sú na reálnych tepelných siet’ach sústav centralizovaného zásobovania teplom, nakol'ko sa hydraulike vonkajšej časti vykurovacej sústavy nevenuje dostatočná pozornost'. Rekonštrukciou pôvodných primárnych rozvodov tepla a výmenou obehového čerpadla na vybranom úseku možno dosiahnut' hydraulickú stabilitu sústavy a úsporu prevádzkových nákladov.
\end{abstract}

\section{Kl’účové slová}

Hydraulika, primárny rozvod tepla, centralizované zásobovanie teplom, obehové čerpadlo, tlakový diagram

\begin{abstract}
The paper deals with the comparison of hydraulic conditions in the primary heating network of a selected section of the district heating system. The calculated state was compared with the actual state before the renovation of buildings and the calculated state with the expected state after the renovation of buildings connected to the district heating system. The aim of the paper is to point out the disproportions that exist in the real heating networks of district heating systems through pressure diagrams, as the hydraulics of the outer part of the heating system are not given sufficient attention. By reconstructing the original primary heat distribution and replacing the circulation pump on a selected section, hydraulic stability of the system and savings in operating costs can be achieved.
\end{abstract}

Key words

Hydraulics, primary heating network, district heating system, circulating pump, pressure diagram

\section{1 ÚVOD}

Najväčší rozvoj sústav centralizovaného zásobovania teplom (SCZT) a ich uvádzanie do prevádzky na Slovensku prebiehalo v závislosti od regiónu v období rokov 1948 až 1989 [1]. Od tohto obdobia prešla väčšina objektov pripojených na SCZT stavebnými úpravami - výmenou transparentných konštrukcí a zateplením ich obvodového plášta. Tieto opatrenia síce zlepšujú tepelnotechnické vlastnosti budov, čo vedie $\mathrm{k}$ zníženiu potreby tepla na vykurovanie, ale zdroje tepla a tepelné siete zostávajú pôvodné, a tým dochádza $\mathrm{k}$ nerovnomernej dodávke tepla. Zníženú potrebu tepla na vykurovanie je potrebné prispôsobit' a v d’alšom kroku vyregulovat' celú vykurovaciu sústavu, čím sa zabezpečí jej hydraulická stabilita [2].

\section{OPIS SÚČASNÉHO STAVU}

Porovnávanie hydraulických pomerov v primárnej tepelnej sieti pred a po uskutočnení stavebných úprav zateplení obvodového plášt’a a výmene transparentných konštrukcií stavebných objektov (SO) prebehlo na úseku od zdroja tepla (ZT) k odovzdávacej stanici tepla číslo 1 (OST1) okruhu SCZT. Schéma zapojenia tepelnej siete 
SCZT a riešený úsek sú zobrazené na Obr. 1. Skúmaný okruh bol uvedený do prevádzky v roku 1982. Potrubné rozvody primárnej tepelnej siete sa od uvedenia SCZT do prevádzky nemenili - sú pôvodné. Primárna tepelná siet' je dvojrúrová, vedená v teplovodných kanáloch. Potrubia sú izolované minerálnou vlnou [3]. Zaujímavost’ou tejto tepelnej siete je, že vratné potrubia sú oproti prívodným o dimenziu väčšie.

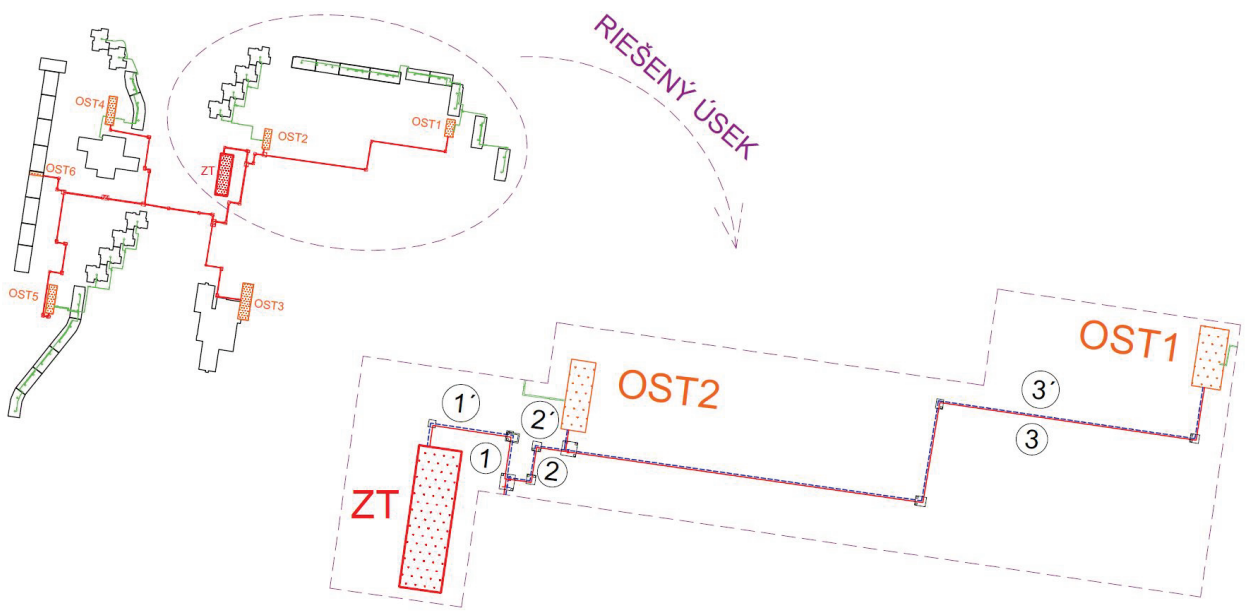

Obr. 1 Schéma zapojenia tepelnej siete sledovanej SCZT a riešený úsek (spracované autorkou podl’a zdroja [3]).

\section{METODIKA POROVNÁVANIA}

Sledovaná SCZT sa porovnávala v dvoch alternatívach:

1. alternatíva - porovnanie výpočtového stavu so skutočným stavom pred obnovou SO pripojených $\mathrm{k}$ SCZT.

2. alternatíva - porovnanie výpočtového stavu s predpokladaným stavom po obnove SO pripojených k SCZT.

\section{Prvá alternatíva}

V tejto 1. alternatíve sa z hl'adiska hydraulických pomerov skúmal stav pred stavebnými úpravami na SO. Porovnával sa výpočtový stav so skutočným stavom. Tepelné bilancie (Q) riešeného okruhu pochádzajú z obdobia pred zateplením SO (rok 2002) a boli poskytnuté prevádzkovatel'om zdroja tepla [3]. Výpočtový teplotný spád v primárnych potrubných rozvodoch sa pred zateplením SO pohyboval na úrovni $100 / 60{ }^{\circ} \mathrm{C}$. Vel'kosti dimenzií (DN) potrubí sú pôvodné.

\section{Výpočtový stav}

Na základe daných tepelných bilancií (potrieb tepla), hmotnostných prietokov a DN primárnych potrubných rozvodov v riešených úsekoch sa z Výpočtových tabuliek pre vykurovanie [4] odčítali prislúchajúce hodnoty merných tlakových strát $(\mathrm{R})$ a rýchlosti prúdenia teplonosnej látky $(\mathrm{w})$. Na tepelné siete sa vzt’ahujú rovnaké výpočtové vzt’ahy ako na teplovodné vykurovacie sústavy, pričom sa rozlišujú tlakové straty trením $(R$. 1) a vradenými odpormi (Z) [5], [6]. Tlakové straty vradenými odpormi boli pre každý úsek samostatne prepočítané.

V Tab. 1 sú spracované prepočty tlakových pomerov pre výpočtový stav. Obehové čerpadlo, musí okrem

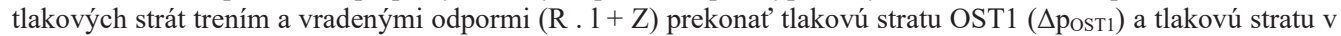
zdroji tepla $\left(\Delta \mathrm{p}_{\mathrm{ZT}}\right)$. Tlaková strata $\Delta \mathrm{p}_{\mathrm{OST} 1}=83 \mathrm{kPa}$ zahŕňa samotnú tlakovú stratu OST a tlakovú stratu armatúr pred a za OST. Pri stanovení potrebného pracovného tlaku čerpadla $(\Delta$ pč) v ZT sa vychádzalo zo vzt’ahu (1).

$$
\Delta p_{\check{\mathrm{C}}}=1,1 \cdot\left(\Sigma(\mathrm{R} \cdot \mathrm{l})+\Sigma(\mathrm{Z})+\Delta p_{O S T}\right) \quad(\mathrm{Pa}),
$$

kde 1,1 - predstavuje zvýšenie tlaku čerpadla na prekonanie tlakovej straty v ZT, $\Sigma(R$. l) - tlaková strata trením v primárnych potrubných rozvodoch $(\mathrm{Pa}), \Sigma(\mathrm{Z})$ - tlaková strata vradenými odpormi $(\mathrm{Pa}), \triangle p_{\mathrm{OST}}$ - tlaková strata OST (Pa) [5]. 
Tab. 1 Tlakové pomery v primárnom potrubí pre výpočtový stav 1. alternatívy [autorka].

\begin{tabular}{|c|c|c|c|c|c|c|c|c|c|}
\hline Úsek & $\begin{array}{c}\mathbf{Q} \\
(\mathbf{k W})\end{array}$ & $\begin{array}{c}M \\
(\mathrm{~kg} / \mathrm{h})\end{array}$ & $\begin{array}{c}\mathrm{d} \\
(\mathrm{mm})\end{array}$ & $\begin{array}{c}\text { I } \\
(\mathrm{m})\end{array}$ & $\begin{array}{c}W \\
(\mathrm{~m} / \mathrm{s})\end{array}$ & $\begin{array}{c}\mathrm{R} \\
(\mathrm{Pa} / \mathrm{m})\end{array}$ & $\begin{array}{l}\text { R. I } \\
\text { (Pa) }\end{array}$ & $\begin{array}{c}\mathrm{Z} \\
(\mathbf{P a})\end{array}$ & $\begin{array}{c}\mathbf{R} \cdot \mathbf{l}+\mathbf{Z} \\
\text { (Pa) }\end{array}$ \\
\hline 1 & 12845 & 276105 & 250 & 39 & 1,5 & 68,7 & 2679 & 656 & 3335 \\
\hline 2 & 4120 & 88560 & 150 & 31 & 1,5 & 121,4 & 3769 & 13838 & 17601 \\
\hline 3 & 2274 & 48880 & 125 & 248 & 1,2 & 101,3 & 25122 & 2239 & 27361 \\
\hline $3^{\prime}$ & 2274 & 48880 & 150 & 248 & 0,78 & 38,54 & 9558 & 935 & 10493 \\
\hline $2^{\prime}$ & 4120 & 88560 & 200 & 31 & 0,74 & 23,78 & 737 & 1998 & 2735 \\
\hline $1^{\prime}$ & 12845 & 276105 & 300 & 39 & 1,0 & 28,23 & 1101 & 306 & 1407 \\
\hline \multicolumn{9}{|c|}{ Tlakové straty trením a vradenými odpormi } & 62933 \\
\hline \multicolumn{9}{|c|}{ Tlaková strata OST } & 83000 \\
\hline \multicolumn{9}{|c|}{ Tlaková strata v zdroji tepla } & 14593 \\
\hline \multicolumn{9}{|c|}{ Výsledný požadovaný pracovný tlak obehového čerpadla } & 160526 \\
\hline
\end{tabular}

Z Tab. 1 je zrejmé, že na optimálnu prevádzku existujúcej časti SCZT by pri hmotnostnom prietoku $\mathrm{M}=276105 \mathrm{~kg} / \mathrm{h}$ postačovalo obehové čerpadlo s dopravnou výškou $\mathrm{H}_{1}=16,1 \mathrm{~m}$.

\section{Skutočný stav}

V projektovej dokumentácii z obdobia pred stavebnými úpravami SO sa uvádza, že dopravná výška obehového čerpadla činí $\mathrm{H}_{2}=33,3 \mathrm{~m}$. Výrobca požaduje pre OST $\Delta$ pOST1 $=90 \mathrm{kPa}$. Na základe vzt’ahu pre výpočet potrebného pracovného tlaku čerpadla (1) je možné odvodit' približné tlakové straty trením a miestnymi odpormi $(\mathrm{R} .1+\mathrm{Z}) \mathrm{v}$ potrubí a následne sa rozdielom pracovného tlaku čerpadla $(\Delta \mathrm{pč})$ a predbežných tlakových strát trením a miestnymi odpormi dopracovat' $\mathrm{k}$ predbežnej tlakovej strate $\mathrm{v}$ zdroji tepla $\left(\Delta \mathrm{p}_{\mathrm{ZT}}\right)$. Prostredníctvom výpočtového vzt'ahu mernej tlakovej straty (R) v potrubí (2), sa stanovila vel'kost' skutočnej mernej tlakovej straty (R).

$$
R=\frac{\left(\Delta \mathrm{p}_{\check{C}}-\Delta \mathrm{p}_{Z T}\right) \cdot(1-a)}{\Sigma l} \quad(P a / m)
$$

kde $\Delta p_{\check{C}}$ - pracovný tlak čerpadla $(\mathrm{Pa}), \Delta p_{\mathrm{ZT}}$ - tlaková strata zdroja tepla $(\mathrm{Pa}), a$ - podiel vradených odporov pre tepelné siete SCZT - v závislosti od zložitosti siete a $=0,1$ až $0,2, \Sigma l$ - celková dížka primárnych potrubných rozvodov tepla $(\mathrm{m})[5]$.

Vel'kosti merných tlakových strát (R) v jednotlivých úsekoch boli odhadované s tým, aby sa približili vypočítanej skutočnej mernej tlakovej strate $\mathrm{R}=380 \mathrm{~Pa} / \mathrm{m}$. Na základe skutočných DN potrubí a odhadovanej mernej tlakovej straty (R) v prívodnom potrubí sa z Výpočtových tabuliek pre vykurovanie [4] odčítali prislúchajúce hodnoty rýchlosti prúdenia teplonosnej látky $(\mathrm{w})$. Následne došlo k prepočtu tlakových strát trením (R . 1) a miestnymi odpormi (Z). V Tab. 2 sú spracované prepočty tlakových pomerov pre skutočný stav s nevhodným obehovým čerpadlom.

Tab. 2 Tlakové pomery v primárnom potrubí pre skutočný stav 1. alternatívy [autorka].

\begin{tabular}{|c|c|c|c|c|c|c|c|c|c|}
\hline Úsek & $\begin{array}{c}\mathbf{Q} \\
(\mathbf{k W})\end{array}$ & $\begin{array}{c}\mathrm{M} \\
(\mathrm{kg} / \mathrm{h})\end{array}$ & $\begin{array}{c}\mathrm{d} \\
(\mathrm{mm})\end{array}$ & $\begin{array}{c}\text { l } \\
(\mathrm{m})\end{array}$ & $\begin{array}{c}\mathbf{w} \\
(\mathrm{m} / \mathrm{s})\end{array}$ & $\begin{array}{c}\mathbf{R} \\
(\mathrm{Pa} / \mathrm{m})\end{array}$ & $\begin{array}{l}\text { R. I } \\
\text { (Pa) }\end{array}$ & $\begin{array}{c}\mathrm{Z} \\
(\mathbf{P a})\end{array}$ & $\begin{array}{l}\mathbf{R} \cdot \mathbf{l}+\mathbf{Z} \\
\text { (Pa) }\end{array}$ \\
\hline 1 & 12845 & 276105 & 250 & 39 & 3,4 & 350 & 13650 & 3370 & 17020 \\
\hline 2 & 4120 & 88560 & 150 & 31 & 2,5 & 380 & 11780 & 38439 & 50219 \\
\hline 3 & 2274 & 48880 & 125 & 248 & 2,1 & 350 & 86800 & 6857 & 93657 \\
\hline $3^{\prime}$ & 2274 & 48880 & 150 & 248 & 1,5 & 130 & 32240 & 3459 & 35699 \\
\hline $2^{\prime}$ & 4120 & 88560 & 200 & 31 & 1,3 & 70 & 2170 & 6167 & 8337 \\
\hline $1^{\prime}$ & 12845 & 276105 & 300 & 39 & 2,4 & 145 & 5655 & 1763 & 7418 \\
\hline \multicolumn{9}{|c|}{$\begin{array}{c}\text { Tlakové straty trením a vradenými odpormi } \\
\text { Tlaková strata OST }\end{array}$} & $\begin{array}{c}212350 \\
90000\end{array}$ \\
\hline \multicolumn{9}{|c|}{ Tlaková strata v zdroji tepla } & 30235 \\
\hline \multicolumn{9}{|c|}{ Skutočný pracovný tlak obehového čerpadla } & 332585 \\
\hline
\end{tabular}

Na Obr. 2 sú prostredníctvom tlakových diagramov zobrazené tlakové pomery v primárnej tepelnej sieti vybraného okrsku SCZT pri výpočtovom stave a pri skutočnom stave pred stavebnými úpravami na SO. 


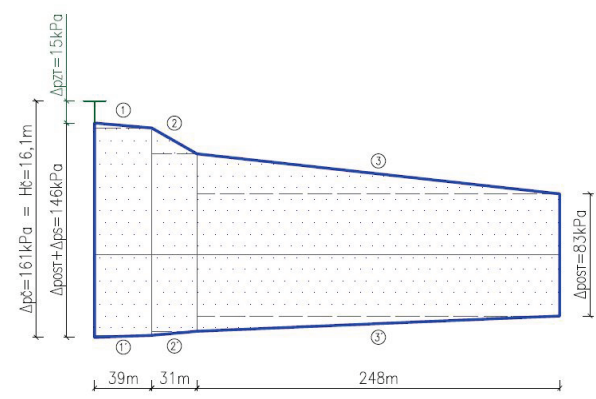

a)

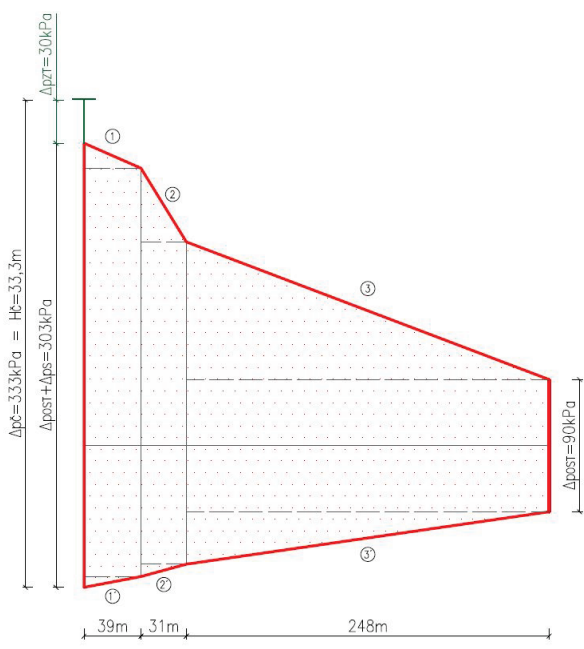

b)

Obr. 2 Priebeh tlakových diagramov pred obnovou SO [autorka]

a) výpočtový stav, b) skutočný stav.

Porovnaním týchto tlakových diagramov možno konštatovat', že zvolené obehové čerpadlo s dopravnou výškou $\mathrm{H}_{2}=33,3 \mathrm{~m}$ bolo pre danú SCZT nevhodne (nesprávne) navrhnuté - predimenzované. Týmto predimenzovaním obehového čerpadla dochádza k nadmernému zvýšeniu rýchlostí prúdenia teplonosnej látky (w) - takmer na dvojnásobok, a tým aj k nárastu tlakových strát v rozvodoch tepla, čo vedie k celkovému rozladeniu a nestabilite hydraulických pomerov v časti SCZT. Pri rešpektovaní potrieb tepla a existujúcich DN potrubí, by na pokrytie tlakových strát v tomto prípade postačovalo obehové čerpadlo s dopravnou výškou $\mathrm{H}_{1}=16,1 \mathrm{~m}$.

\section{Druhá alternatíva}

V tejto 2. alternatíve sa z hl'adiska hydraulických pomerov skúmal stav po stavebných úpravách na SO. Porovnával sa výpočtový stav s predpokladaným stavom. Tepelné bilancie (Q) riešeného okruhu pochádzajú z obdobia po zateplení SO (rok 2019) a boli poskytnuté prevádzkovatel'om zdroja tepla [3]. Výpočtový teplotný spád v primárnych potrubných rozvodoch sa po zateplení SO znížil na úroveň $85 / 60^{\circ} \mathrm{C}$. Vel'kosti DN potrubí sú pôvodné.

\section{Výpočtový stav}

Metodika stanovenia tlakových pomerov je totožná s 1. alternatívou, pričom sa vplyvom obnovy SO tepelné bilancie zmenšili o tretinu. Na optimálnu prevádzku existujúcej časti SCZT by pri hmotnostnom prietoku $\mathrm{M}=167627 \mathrm{~kg} / \mathrm{h}$ postačovalo obehové čerpadlo s dopravnou výškou $\mathrm{H}_{3}=11,6 \mathrm{~m}$.

\section{Predpokladaný stav}

V tomto prípade predpokladáme, že po stavebných úpravách na SO nedošlo k výmene obehového čerpadla a v ZT bolo ponechané pôvodné s dopravnou výškou $\mathrm{H}_{2}=33,3 \mathrm{~m}$. Postup úvahy a výpočtu tlakových pomerov je teda rovnaký ako pri predpokladanom stave pri 1. alternatíve.

Na Obr. 3 sú prostredníctvom tlakových diagramov zobrazené tlakové pomery v primárnej tepelnej sieti vybraného okrsku SCZT pri výpočtovom stave a pri predpokladanom stave po stavebných úpravách na SO.

Porovnaním týchto tlakových diagramov možno konštatovat', že zvolené obehové čerpadlo s dopravnou výškou $\mathrm{H}_{2}=33,3 \mathrm{~m}$ by bolo pre danú SCZT nevhodne navrhnuté - predimenzované. Týmto predimenzovaním dochádza k nadmernému zvýšeniu rýchlostí prúdenia teplonosnej látky - takmer na trojnásobok, a tým aj k nárastu tlakových strát v rozvodoch tepla, čo vedie k celkovému rozladeniu a nestabilite hydraulických pomerov v časti SCZT. Pri rešpektovaní potrieb tepla a existujúcich DN potrubí, by na pokrytie tlakových strát v tomto prípade postačovalo obehové čerpadlo s dopravnou výškou $\mathrm{H}_{3}=11,6 \mathrm{~m}$. 


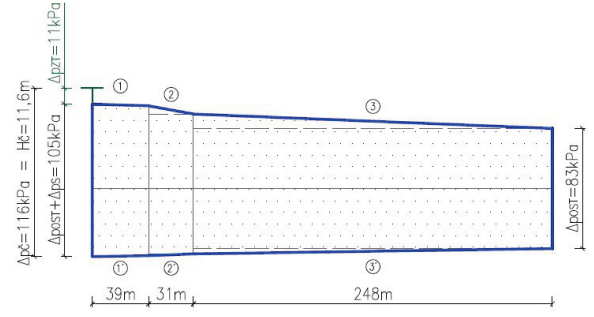

a)

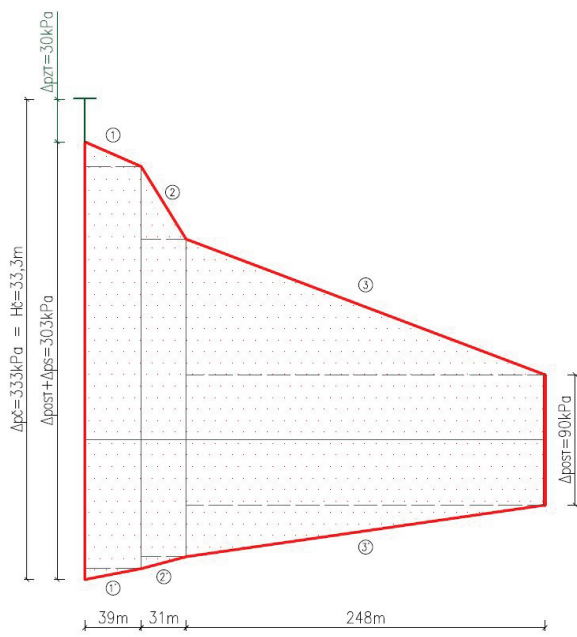

b)

Obr. 3 Priebeh tlakových diagramov po obnove SO [autorka]

a) výpočtový stav, b) predpokladaný stav.

\section{VYHODNOTENIE}

Vzhl'adom k tomu, že sa priebeh tlakových pomerov pri predpokladanom stave po obnove SO oproti skutočnému stavu pred obnovou SO nezmenil - nedošlo k výmene čerpadla, daný okruh možno považovat' za hydraulicky nestabilný. Nakol'ko obnova SO spôsobila znížený dopyt po dodávke tepla, došlo aj k zníženiu samotných hmotnostných prietokov. Odporúčaným - ideálnym riešením pre takéto sústavy je výmena pôvodných obehových čerpadiel za nové progresívne (s frekvenčnou zmenou otáčok), ktoré sú energeticky hospodárnejšie.

\section{Ideálny - výpočtový stav}

Z hl'adiska hydraulických pomerov sa skúmal stav po stavebných úpravách na SO a zmene DN potrubí. Tepelné bilancie (Q) riešeného okruhu pochádzajú zobdobia po zateplení SO (rok 2019) a boli poskytnuté prevádzkovatel'om zdroja tepla [3]. Výpočtový teplotný spád v primárnych potrubných rozvodoch sa po zateplení SO pohybuje na úrovni $85 / 60^{\circ} \mathrm{C}$. Vel'kosti DN potrubí sú nové.

V Tab. 3 sú spracované prepočty tlakových pomerov pre ideálny stav. Na základe daných tepelných bilancií (Q) a hmotnostných prietokov teplonosnej látky $(\mathrm{M})$ došlo k novému návrhu DN primárnych rozvodov tepla.

Tab. 3 Tlakové pomery v primárnom potrubí po obnove SO a výmene rozvodov tepla [autorka].

\begin{tabular}{|c|c|c|c|c|c|c|c|c|c|}
\hline Úsek & $\begin{array}{c}\mathbf{Q} \\
(\mathbf{k W})\end{array}$ & $\begin{array}{c}\text { M } \\
(\mathrm{kg} / \mathrm{h})\end{array}$ & $\begin{array}{c}\mathrm{d} \\
(\mathrm{mm})\end{array}$ & $\begin{array}{c}\text { l } \\
(\mathrm{m})\end{array}$ & $\begin{array}{c}\mathrm{w} \\
(\mathrm{m} / \mathrm{s})\end{array}$ & $\begin{array}{c}\mathbf{R} \\
(\mathrm{Pa} / \mathrm{m})\end{array}$ & $\begin{array}{l}\mathrm{R} . \mathrm{l} \\
(\mathrm{Pa})\end{array}$ & $\begin{array}{c}\mathrm{Z} \\
(\mathbf{P a})\end{array}$ & $\begin{array}{c}\mathbf{R} . \mathbf{l}+\mathbf{Z} \\
\quad \text { (Pa) }\end{array}$ \\
\hline 1 & 4874 & 167627 & 200 & 39 & 1,45 & 84 & 3276 & 613 & 3889 \\
\hline 2 & 1430 & 49181 & 150 & 31 & 0,8 & 39 & 1209 & 4684 & 5893 \\
\hline 3 & 842 & 28958 & 125 & 248 & 0,7 & 37 & 9176 & 674 & 9850 \\
\hline $3^{\prime}$ & 842 & 28958 & 125 & 248 & 0,7 & 37 & 9176 & 674 & 9850 \\
\hline $2^{\prime}$ & 1430 & 49181 & 150 & 31 & 0,8 & 39 & 1209 & 3723 & 4932 \\
\hline $1^{\prime}$ & 4874 & 167627 & 200 & 39 & 1,45 & 84 & 3276 & 613 & 3889 \\
\hline \multicolumn{9}{|c|}{ Tlakové straty trením a vradenými odpormi } & 38303 \\
\hline \multicolumn{9}{|c|}{ Tlaková strata OST } & 82000 \\
\hline \multicolumn{9}{|c|}{ Tlaková strata v zdroji tepla } & 12030 \\
\hline \multicolumn{9}{|c|}{ Výsledný požadovaný pracovný tlak obehového čerpadla } & 132333 \\
\hline
\end{tabular}

Z Tab. 3 je zrejmé, že na ideálnu prevádzku časti SCZT by pri hmotnostnom prietoku M $=167627 \mathrm{~kg} / \mathrm{h}$ postačovalo obehové čerpadlo s dopravnou výškou $\mathrm{H}_{4}=13,3 \mathrm{~m}$. 
Na Obr. 4 sú prostredníctvom tlakového diagramu zobrazené tlakové pomery v primárnej tepelnej sieti vybraného úseku SCZT pri ideálnom stave po obnove SO a výmene pôvodných DN potrubí za nové.

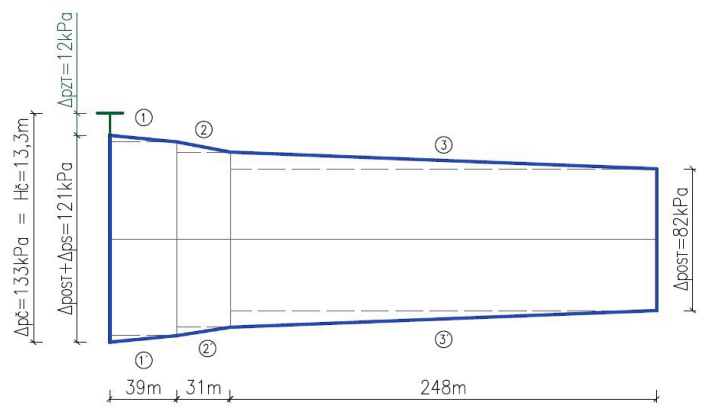

Obr. 4 Tlakový diagram po obnove SO a výmene rozvodov tepla [autorka].

\section{DISKUSIA}

Návrhom obehového čerpadla s dopravnou výškou $\mathrm{H}_{4}=13,3 \mathrm{~m}$ s podstatne nižšou spotrebou elektrickej energie a výmenou pôvodných DN primárnych rozvodov tepla SCZT je možné dosiahnut' značné úspory čerpacej práce, ktorá prispeje k zvýšeniu hospodárnosti a hydraulickej stabilite rekonštruovanej SCZT. Takéto riešenie je jednou z ciest, ako zefektívňovat’ prevádzky SCZT v budúcnosti.

\section{ZÁVER}

Ciel’om príspevku bolo poukázat' na disproporcie, ktoré sú na reálnych primárnych tepelných siet’ach SCZT. V prvej časti tejto analýzy je výsledok v podobe tlakového diagramu pre výpočtový a reálny stav s pôvodným čerpadlom a pôvodným potrubným rozvodom pred obnovou SO. Z Obr. 2 je jasné, že pôvodné čerpadlo s dopravnou výškou $\mathrm{H}_{2}=33,3 \mathrm{~m}$ bolo nesprávne volené, pričom aj hydraulická stabilita potrubnej siete je otázna. Paradoxom je, že aj po zateplení SO a výmene okien sa problematike obehových čerpadiel nevenovala patričná pozornost'. Výmena obehového čerpadla za nové s nižšou dopravnou výškou by bola vhodná alternatíva. Ak by sa uskutočnila rekonštrukcia pôvodných tepelných sietí, tak by mohla sledovaná SCZT pracovat' tak, ako je to naznačené na tlakovom diagrame na Obr. 4 a postačovalo by obehové čerpadlo s dopravnou výškou $\mathrm{H}_{4}=13,3 \mathrm{~m}$. Hlavnou výhodou navrhovaného riešenia by bola úspora prevádzkových nákladov na d'alšie prevádzkové obdobie.

\section{Pod'akovanie}

Príspevok bol podporovaný Ministerstvom školstva, vedy, výskumu a športu SR prostredníctvom grantov VEGA 1/0304/21, VEGA 1/0303/21 a KEGA 005/STU-4/2021.

\section{Použité zdroje}

[1] Sústavy centrálneho zásobovania teplom - prehl'ad súčasného stavu. [online]. Slovenská inovačná a energetická agentúra: SIEA. Bratislava. 2014. Dostupné na internete: <https://www.siea.sk/wpcontent/uploads/poradenstvo/analyzy/Systemy_CZT_SIEA_2014_pdf $>$

[2] TAKÁCS, J. - DERZSI, I.: Hydraulické pomery v bytových domoch po zateplení. Správa budov. 2017, roč. 11 , č. 4, s. 43-45. ISSN 1337-6233.

[3] Firemné podklady energetickej spoločnosti.

[4] LABOUTKA, K. - SUCHÁNEK, T.: Výpočtové tabulky pro vytápění, vztahy a pomůcky. Praha 1: Společnost pro techniku prostředí, 2001. 208 s. ISBN 80-02-01466-9.

[5] PEKAROVIČ, J. K. a kol.: Vykurovanie I. a II. Bratislava: Vydavatel'stvo STU v Bratislave, 1994. 493 s. ISBN 80-227-0648-5.

[6] PETRÁS̆, D. a kol.: Vykurovanie rodinných a bytových domov. Bratislava: Vydavatel'stvo Jaga group, 2005. 246 s. ISBN 80-807-6012-8. 